\title{
Rubellimicrobium aerolatum sp. nov., isolated from an air sample in Korea
}

\author{
Hang-Yeon Weon, ${ }^{1}$ Jung-A Son, ${ }^{1}$ Seung-Hee Yoo, ${ }^{2}$ Seung-Beom Hong, ${ }^{2}$ \\ Young-Ah Jeon, ${ }^{2}$ Soon-Wo Kwon ${ }^{2}$ and Bon-Sung Koo ${ }^{2}$
}

\begin{abstract}
Correspondence
Soon-Wo Kwon

swkwon@rda.go.kr
\end{abstract}

\author{
${ }^{1}$ Applied Microbiology Division, National Institute of Agricultural Science and Technology, Rural \\ Development Administration, Suwon 441-707, Republic of Korea \\ ${ }^{2}$ Korean Agricultural Culture Collection (KACC), Microbial Genetics Division, National Institute of \\ Agricultural Biotechnology, Rural Development Administration, Suwon 441-707, Republic of Korea
}

The Roseobacter clade or the 'Roseobacter-SulfitobacterSilicibacter' group (Wagner-Döbler et al., 2003) was named after the genus Roseobacter by Giovannoni \& Rappé (2000). The members of this group were found largely in marine environments (González \& Moran, 1997; Eilers et al., 2000; Rappé et al., 2000; Zubkov et al., 2001). Among them, two closely related novel members, Rubellimicrobium thermophilum (Denner et al., 2006) and Wenxinia marina (Ying et al., 2007), were reported recently, having been isolated from biofilms from fine-paper machines and a pulp dryer, and from an oilfield sediment from the South China Sea, respectively. Most recently, a novel member of the genus Rubellimicrobium, Rubellimicrobium mesophilum, was proposed for a soil isolate (Dastager et al., 2008).

In our study of the microbial diversity of air samples collected in the Suwon region of the Republic of Korea, a pinkcoloured strain, designated $5715 \mathrm{~S}-\mathrm{9}^{\mathrm{T}}$, was obtained. Air samples were collected with an MAS-100 air sampler (Merck) (single-stage multiple-hole impactor) containing Petri dishes with R2A agar (BBL) amended with $200 \mu \mathrm{g}$ cycloheximide

The GenBank/EMBL/DDBJ accession number for the 16S rRNA gene sequence of strain $5715 \mathrm{~S}-9^{\top}$ is EU338486.

A transmission electron micrograph of cells of strain $5715 \mathrm{~S}-9^{\top}$ and twodimensional thin-layer chromatograms of polar lipid extracts obtained from strain 5715S-9 ${ }^{\top}$ and Rubellimicrobium thermophilum DSM $16684^{\top}$ are available as supplementary material with the online version of this paper. $\mathrm{ml}^{-1}$ (Sigma). After sampling, the plates were incubated at $30{ }^{\circ} \mathrm{C}$ for 5 days and strain $5715 \mathrm{~S}-9^{\mathrm{T}}$ was recovered.

The 16S rRNA gene was amplified by using PCR with primers $\mathrm{fD} 1$ and rP2 (Weisburg et al., 1991) on colonies; the entire PCR fragment was directly sequenced (Hiraishi, 1992). The closest known relatives of the novel isolate were determined by performing GenBank/EMBL/DDBJ database searches. After multiple alignments of the data had been performed using CLUSTAL W (Thompson et al., 1994), the software package MEGA, version 3.1 (Kumar et al., 2004), was used for all analyses. Phylogenetic dendrograms were constructed using the neighbour-joining (Saitou \& Nei, 1987) and maximum-parsimony (Fitch, 1971) methods and bootstrap percentages based on 1000 replications. For strain $5715 \mathrm{~S}-9^{\mathrm{T}}, 1354 \mathrm{bp}$ of the $16 \mathrm{~S}$ rRNA gene sequence were determined. The strain was found to be a member of the genus Rubellimicrobium. The highest levels of sequence similarity for strain $5715 \mathrm{~S}-9^{\mathrm{T}}$ occurred with respect to Rubellimicrobium mesophilum MSL- $20^{\mathrm{T}}$ (96.2\% sequence similarity), Rubellimicrobium thermophilum DSM $16684^{\mathrm{T}}$ $(93.9 \%)$ and W. marina JCM $14017^{\mathrm{T}}(91.5 \%)$; less than $91.0 \%$ similarity was shown with respect to the type strains of all the other taxa tested. In the neighbour-joining tree (Fig. 1), strain $5715 \mathrm{~S}-9^{\mathrm{T}}$ clearly formed a lineage with Rubellimicrobium mesophilum and Rubellimicrobium thermophilum, as shown by the $100 \%$ bootstrap support. This result was also supported by the maximum-parsimony tree. 


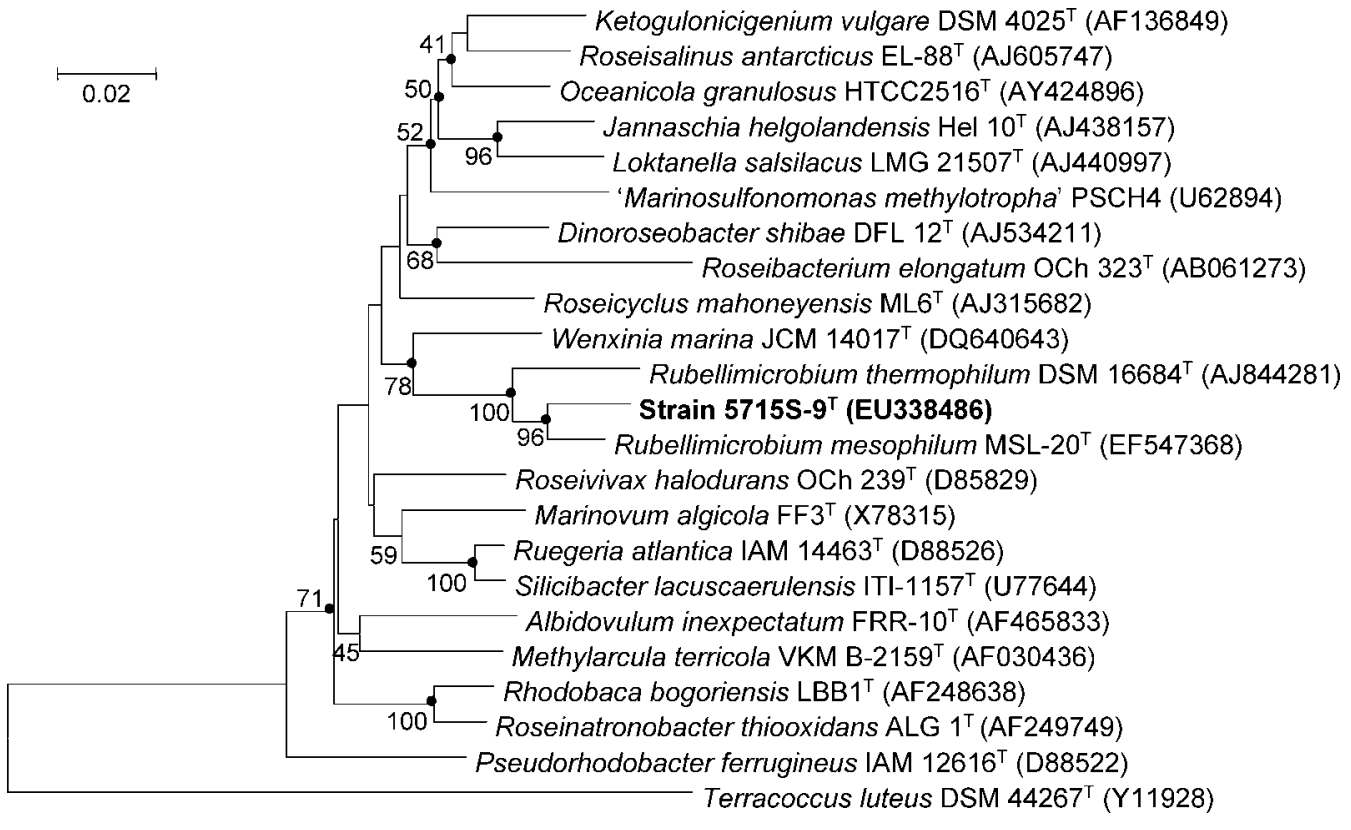

Fig. 1. Neighbour-joining phylogenetic tree, based on 16S rRNA gene sequences, showing the relationships between strain $5715 S-9^{\top}$ and some members of the Alphaproteobacteria. Bootstrap percentages (based on 1000 replications) $>40 \%$ are shown at branch points. Filled circles indicate that the corresponding branches were also recovered in the maximum-parsimony tree. Bar, 0.02 substitutions per nucleotide position.

Gram staining, catalase and oxidase activities and hydrolysis of carboxymethylcellulose, casein, chitin (from crab shells), DNA, hypoxanthine, pectin, starch, Tween 80, tyrosine and xanthine were tested using the methods of Smibert \& Krieg (1994). Cell morphology and motility were investigated under a phase-contrast microscope and with transmission electron microscopy, using cells negatively stained with $0.5 \%$ uranyl acetate after growth on $\mathrm{R} 2 \mathrm{~A}$ medium. The optimum $\mathrm{pH}$ range for growth was examined in $\mathrm{R} 2 \mathrm{~A}$ broth adjusted to various $\mathrm{pH}$ values ( $\mathrm{pH} 4-10$, using increments of $1.0 \mathrm{pH}$ unit). Strain $5715 \mathrm{~S}-9^{\mathrm{T}}$ was tested for its tolerance of $\mathrm{NaCl}$ by using $\mathrm{R} 2 \mathrm{~A}$ broth at various $\mathrm{NaCl}$ concentrations $(0,1,2,3$ and $5 \%, \mathrm{w} / \mathrm{v})$. The optimum temperature for growth of the strain was determined by testing various temperatures $\left(5-45^{\circ} \mathrm{C}\right.$, using increments of $5{ }^{\circ} \mathrm{C}$ ) on R2A agar. Growth under anaerobic conditions was determined after incubating the strain in a GasPak (BBL) jar at $30{ }^{\circ} \mathrm{C}$ for 15 days. Physiological and biochemical properties were determined further using API ZYM, API 20NE, API $50 \mathrm{CH}$ and API ID 32GN (all from bioMérieux). Tests in the commercial systems were generally performed according to the manufacturer's instructions. Whole-cell fatty acids were analysed according to the standard protocol of the MIDI/Hewlett Packard Microbial Identification System (Sasser, 1997). Isoprenoid quinones were extracted and analysed as described by Groth et al. (1996). The DNA G + C content was determined by means of HPLC analysis of deoxyribonucleosides, as described by Mesbah et al. (1989), using a reversed-phase column (Supelcosil LC-18 S; Supelco).
Strain $5715 \mathrm{~S}-9^{\mathrm{T}}$ grew on R2A but not on nutrient agar (Difco), tryptic soy agar (Difco) or MacConkey agar (Difco). Transmission electron microscopy revealed that cells of strain $5715 \mathrm{~S}-9^{\mathrm{T}}$ had no flagella (see Supplementary Fig. S1, available in IJSEM Online). Differential physiological characteristics for strain $5715 \mathrm{~S}-9^{\mathrm{T}}$ and the species most closely related to it are given in Table 1 . The major cellular fatty acids of strain $5715 \mathrm{~S}-9^{\mathrm{T}}$ were $\mathrm{C}_{18: 1} \omega 7 \mathrm{c}$ $(56.5 \%), \quad \mathrm{C}_{16: 0} \quad(16.6 \%)$ and 11-methyl $\mathrm{C}_{18: 1} \omega 7 c$ $(10.4 \%)$. The detailed fatty acid compositions of strain $5715 \mathrm{~S}-9^{\mathrm{T}}$ and its close phylogenetic neighbours are shown in Table 2. The main isoprenoid quinone was Q-10. The polar lipids comprised phosphatidylglycerol, phosphatidylcholine, diphosphatidylglycerol, phosphatidylethanolamine and an unidentified glycolipid; two-dimensional thin-layer chromatograms of the polar lipids from strain $5715 \mathrm{~S}-9^{\mathrm{T}}$ and Rubellimicrobium thermophilum DSM $16684^{\mathrm{T}}$ are shown in Supplementary Fig. S2 (available in IJSEM Online). The DNA G $+\mathrm{C}$ content was $69 \mathrm{~mol} \%$.

According to the phylogenetic tree (Fig. 1), strain 5715S-9 ${ }^{\mathrm{T}}$ belongs in the genus Rubellimicrobium. However, it could be differentiated from the closest relative, Rubellimicrobium mesophilum, on the basis of the presence of catalase and oxidase, growth at $35^{\circ} \mathrm{C}$ and the differences in fatty acid compositions. In addition, the strain is clearly separable from Rubellimicrobium thermophilum on the basis of the colony colour (pink versus red), the absence of flagella, the dearth of hydrolytic and assimilative activities and the fatty acid compositions (Tables 1 and 2). On the basis of the 
Table 1. Differential phenotypic characteristics of strain $5715 \mathrm{~S}-9^{\top}$ and closely related taxa

Strains: 1, 5715S-9 ${ }^{\mathrm{T}}$ (Rubellimicrobium aerolatum sp. nov.); 2, Rubellimicrobium mesophilum MSL-20 ${ }^{\mathrm{T}}$ (data from Dastager et al., 2008); 3, Rubellimicrobium thermophilum DSM $16684^{\mathrm{T}}$ (Denner et al., 2006; this study); 4, W. marina HY34 ${ }^{\mathrm{T}}$ (Ying et al., 2007). +, Positive; (+), weakly positive; -, negative; ND, not determined.

\begin{tabular}{|c|c|c|c|c|}
\hline Characteristic & 1 & 2 & 3 & 4 \\
\hline Source of isolation & Air & Soil & Biofilms* & Marine sediment \\
\hline Colony colour & Pink & Pink to light reddish & $\operatorname{Red}^{*}$ & Faint pink \\
\hline Flagellation & - & - & Polar flagella* & - \\
\hline Catalase/oxidase & $+1+$ & $-1-$ & $+/+$ & $+1+$ \\
\hline Growth at $35{ }^{\circ} \mathrm{C}$ & + & - & $+^{\star}$ & + \\
\hline Tolerance of $\mathrm{NaCl}(\%)$ & $\leqslant 1$ & $<1$ & ND & $\leqslant 9$ \\
\hline Nitrate reduction & - & - & - & + \\
\hline Urease & - & ND & - & + \\
\hline \multicolumn{5}{|l|}{ Hydrolysis of: } \\
\hline Aesculin & - & ND & + & ND \\
\hline Gelatin & - & ND & + & ND \\
\hline \multicolumn{5}{|l|}{ Assimilation of: } \\
\hline L-Alanine & - & ND & + & $(+)$ \\
\hline L-Arabinose & - & ND & + & $\mathrm{ND}$ \\
\hline L-Fucose & - & ND & + & + \\
\hline D-Glucose & - & ND & + & $\mathrm{ND}$ \\
\hline Lactic acid & - & ND & + & + \\
\hline Malic acid & - & - & - & + \\
\hline D-Mannitol & - & ND & + & - \\
\hline D-Mannose & - & - & + & $\mathrm{ND}$ \\
\hline Melibiose & - & - & + & $(+)$ \\
\hline Potassium gluconate & - & ND & + & + \\
\hline L-Rhamnose & - & - & + & + \\
\hline Sucrose & - & ND & + & + \\
\hline D-Sorbitol & - & - & + & $(+)$ \\
\hline DNA G $+\mathrm{C}$ content $(\mathrm{mol} \%)$ & 69 & 72.3 & $69.4-70.2$ & 69.4 \\
\hline
\end{tabular}

${ }^{\star}$ Data from Denner et al. (2006).

phenotypic and phylogenetic data presented in this study, strain $5715 \mathrm{~S}-9^{\mathrm{T}}$ represents a novel species within the genus Rubellimicrobium, for which the name Rubellimicrobium aerolatum sp. nov. is proposed.

\section{Description of Rubellimicrobium aerolatum sp. nov.}

Rubellimicrobium aerolatum (ae.ro.la'tum. Gr. n. aer air; L. part. adj. latus - $a$-um carried; N.L. part. adj. aerolatum airborne).

Cells are strictly aerobic, Gram-negative, non-motile, nonspore-forming, short rods $(0.8 \mu \mathrm{m}$ wide and 1.6-3.6 long). Colonies are pink-coloured and circular with clear margins. Oxidase- and catalase-positive. Temperature and $\mathrm{pH}$ ranges for growth are $5-35^{\circ} \mathrm{C}$ and $\mathrm{pH} 6-7$, with optima at $30{ }^{\circ} \mathrm{C}$ and $\mathrm{pH}$ 7. Growth occurs in the presence of $0-1 \% \mathrm{NaCl}$, but not with $2 \% \mathrm{NaCl}$. Weakly hydrolyses xanthine but not casein, chitin, carboxymethylcellulose, DNA, hypoxanthine, pectin, starch, tyrosine or Tween 80 . Positive for $\beta$-galactosidase, but negative for nitrate reduction, indole production, glucose fermentation, arginine dihydrolase, urease, aesculin hydrolase and gelatin hydrolase (API 20NE). Does not assimilate any substrates in API 20NE and API ID 32GN kits. Does not form any acids from any of the substrates in the API 50 $\mathrm{CH}$ kit. Positive for $\beta$-glucosidase, weakly positive for alkaline phosphatase, esterase (C4), esterase lipase (C8), leucine arylamidase, naphthol-AS-BI-phosphohydrolase and $\alpha$-glucosidase and negative for lipase (C14), valine arylamidase, cystine arylamidase, trypsin, $\alpha$-chymotrypsin, acid phosphatase, $\alpha$-galactosidase, $\beta$-glucuronidase, $N$ acetyl- $\beta$-glucosaminidase, $\alpha$-mannosidase and $\alpha$-fucosidase (API ZYM). The major isoprenoid quinone system is Q-10. Major polar lipids are phosphatidylglycerol, phosphatidylcholine, diphosphatidylglycerol, phosphatidylethanolamine and an unidentified glycolipid. Major fatty acids (>10\%) are $\mathrm{C}_{18: 1} \omega 7 c, \mathrm{C}_{16: 0}$ and 11-methyl $\mathrm{C}_{18: 1} \omega 7 c$. The DNA $\mathrm{G}+\mathrm{C}$ content of the type strain is $69 \mathrm{~mol} \%$.

The type strain, $5715 \mathrm{~S}-9^{\mathrm{T}} \quad\left(=\mathrm{KACC} \quad 12504^{\mathrm{T}}=\mathrm{DSM}\right.$ $19297^{\mathrm{T}}$ ), was isolated from an air sample collected in the Suwon region of the Republic of Korea. 
Table 2. Cellular fatty acid contents of strain $5715 S-9^{\top}$ and closely related strains

Strains: 1, 5715S-9 $9^{\mathrm{T}}$ (Rubellimicrobium aerolatum sp. nov.); 2, Rubellimicrobium mesophilum MSL-20 ${ }^{\mathrm{T}}$ (data from Dastager et al., 2008); 3, Rubellimicrobium thermophilum DSM $16684^{\mathrm{T}}$; 4, W. marina $\mathrm{HY}_{34^{\mathrm{T}}}$ (Ying et al., 2007). Cells of strains $5715 \mathrm{~S}-9^{\mathrm{T}}$ and DSM $16684^{\mathrm{T}}$ were harvested after cultivation on R2A at $30{ }^{\circ} \mathrm{C}$ for 4 days. Data are expressed as percentages of total fatty acids; fatty acids constituting more than $1 \%$ of total fatty acids are shown.,$-<1 \%$ or not detected.

\begin{tabular}{|c|c|c|c|c|}
\hline Fatty acid & 1 & 2 & 3 & 4 \\
\hline $\mathrm{C}_{10: 0}$ & - & 1.3 & - & - \\
\hline $\mathrm{C}_{10: 0} 3-\mathrm{OH}$ & 4.7 & - & 2.2 & - \\
\hline $\mathrm{C}_{12: 0}$ & - & 1.3 & - & 1.6 \\
\hline $\mathrm{C}_{13: 0} 2-\mathrm{OH}$ & - & - & - & 1.2 \\
\hline $\mathrm{C}_{14: 0}$ & - & - & - & 3.7 \\
\hline iso- $\mathrm{C}_{15: 1} \mathrm{G}$ & - & - & - & 3.4 \\
\hline $\mathrm{C}_{17: 0}$ & - & 1.2 & - & - \\
\hline$C_{16: 0}$ & 16.6 & 36.9 & 7.8 & 16.5 \\
\hline $\mathrm{C}_{18: 0}$ & 2.3 & 3.6 & 14.6 & 3.9 \\
\hline $\mathrm{C}_{18: 1} \omega 7 c$ & 56.5 & 36.5 & 45.6 & 57.1 \\
\hline 11-Methyl $\mathrm{C}_{18: 1} \omega 7 c$ & 10.4 & 12.4 & - & 5.4 \\
\hline $\mathrm{C}_{19: 0} \omega 8 c$ cyclo & - & - & 22.3 & - \\
\hline \multicolumn{5}{|l|}{ Unknown fatty acids ${ }^{\star}$} \\
\hline ECL 10.928 & 4.1 & - & - & - \\
\hline ECL 11.799 & - & - & 2.8 & - \\
\hline \multicolumn{5}{|l|}{ Summed features $\dagger$} \\
\hline 3 & 2.4 & - & - & 1.9 \\
\hline 5 & 1.1 & - & - & - \\
\hline
\end{tabular}

${ }^{\star}$ ECL, Equivalent chain-length.

$\dagger$ Summed features are groups of two or three fatty acids that cannot be separated using the MIDI system: summed feature 3 comprises $\mathrm{C}_{16: 1} \omega 7 c$ and/or iso- $\mathrm{C}_{15: 0} 2-\mathrm{OH}$; summed feature 5 comprises $\mathrm{C}_{18: 2} \omega 6,9 c$ and/ or anteiso- $\mathrm{C}_{18: 0}$.

\section{Acknowledgements}

This study was supported by the National Institute of Agricultural Biotechnology (grant no. 06-4-11-19-1), Rural Development Administration, Republic of Korea.

\section{References}

Dastager, S. G., Lee, J.-C., Ju, Y.-J., Park, D.-J. \& Kim, C.-J. (2008). Rubellimicrobium mesophilum sp. nov., a mesophilic, pigmented bacterium isolated from soil in Bigeum Island in Korea. Int J Syst Evol Microbiol 58, 1797-1800.

Denner, E. B. M., Kolari, M., Hoornstra, D., Tsitko, I., Kämpfer, P., Busse, H.-J. \& Salkinoja-Salonen, M. (2006). Rubellimicrobium thermophilum gen. nov., sp. nov., a red-pigmented, moderately thermophilic bacterium isolated from coloured slime deposits in paper machines. Int J Syst Evol Microbiol 56, 1355-1362.

Eilers, H., Pernthaler, J., Glöckner, F. O. \& Amann, R. (2000). Culturability and in situ abundance of pelagic bacteria from the North Sea. Appl Environ Microbiol 66, 3044-3051.

Fitch, W. M. (1971). Toward defining the course of evolution: minimum change for a specific tree topology. Syst Zool 20, 406416.

Giovannoni, S. \& Rappé, M. (2000). Evolution, diversity and molecular ecology of marine prokaryotes. In Microbial Ecology of the Ocean, pp. 47-84. Edited by D. L. Kirchman. New York: Wiley.
González, J. M. \& Moran, M. A. (1997). Numerical dominance of a group of marine bacteria in the $\alpha$-subclass of the class Proteobacteria in coastal seawater. Appl Environ Microbiol 63, 4237-4242.

Groth, I., Schumann, P., Weiss, N., Martin, K. \& Rainey, F. A. (1996). Agrococcus jenensis gen. nov., sp. nov., a new genus of actinomycetes with diaminobutyric acid in the cell wall. Int J Syst Bacteriol 46, 234-239.

Hiraishi, A. (1992). Direct automated sequencing of $16 \mathrm{~S}$ rDNA amplified by polymerase chain reaction from bacterial cultures without DNA purification. Lett Appl Microbiol 15, 210-213.

Kumar, S., Tamura, K. \& Nei, M. (2004). MEGA3: integrated software for molecular evolutionary genetics analysis and sequence alignment. Brief Bioinform 5, 150-163.

Mesbah, M., Premachandran, U. \& Whitman, W. B. (1989). Precise measurement of the $\mathrm{G}+\mathrm{C}$ content of deoxyribonucleic acid by high-performance liquid chromatography. Int J Syst Bacteriol 39, 159-167.

Rappé, M. S., Vergin, K. \& Giovannoni, S. J. (2000). Phylogenetic comparisons of a coastal bacterioplankton community with its counterparts in open ocean and freshwater systems. FEMS Microbiol Ecol 33, 219-232.

Saitou, N. \& Nei, M. (1987). The neighbor-joining method: a new method for reconstructing phylogenetic trees. Mol Biol Evol 4, 406-425.

Sasser, M. (1997). Identification of bacteria by gas chromatography of cellular fatty acids, MIDI Technical Note 101. Newark, DE: MIDI Inc. 
Smibert, R. M. \& Krieg, N. R. (1994). Phenotypic characterization. In Methods for General and Molecular Bacteriology, pp. 607-654. Edited by P. Gerhardt, R. G. E. Murray, W. A. Wood \& N. R. Krieg. Washington, DC: American Society for Microbiology.

Thompson, J. D., Higgins, D. G. \& Gibson, T. J. (1994). ClusTAL W: improving the sensitivity of progressive multiple sequence alignment through sequence weighting, position-specific gap penalties and weight matrix choice. Nucleic Acids Res 22, 4673-4680.

Wagner-Döbler, I., Rheims, H., Felske, D. A., Pukall, R. \& Tindall, B. J. (2003). Jannaschia helgolandensis gen. nov., sp. nov., a novel abundant member of the marine Roseobacter clade from the North Sea. Int J Syst Evol Microbiol 53, 731-738.
Weisburg, W. G., Barns, S. M., Pelletier, D. A. \& Lane, D. J. (1991). 16S ribosomal DNA amplification for phylogenetic study. J Bacteriol 173, 697-703.

Ying, J. Y., Wang, B. J., Dai, X., Yang, S. S., Liu, S. J. \& Liu, Z. P. (2007). Wenxinia marina gen. nov., sp. nov., a novel member of the Roseobacter clade isolated from oilfield sediments of the South China Sea. Int J Syst Evol Microbiol 57, 1711-1716.

Zubkov, M. V., Fuchs, B. M., Archer, S. D., Kiene, R. P., Amann, R. \& Burkill, P. H. (2001). Linking the composition of bacterioplankton to rapid turnover of dissolved dimethylsulphoniopropionate in an algal bloom in the North Sea. Environ Microbiol 3, 304-311. 